\title{
Odmevi sarajevskega atentata: Sodobne reinterpretacije Gavrila Principa v povojni Bosni in Hercegovini
}

Alenka Bartulović

\section{UVOD}

Ob obeležitvi stote obletnice začetka prve svetovne vojne se je mednarodna pozornost znova obrnila k Bosni in Hercegovini ter Sarajevu, prizorišču atentata na Franca Ferdinanda in njegovo soprogo, ki ga je 28. junija 1914 zagrešil Gavrilo Princip. Sarajevski atentat velja za ključen dogodek dvajsetega stoletja, zato ne preseneča, da so številni evropski politični akterji stoto obletnico videli kot odlično priložnost za promocijo miru in sodelovanja $\mathrm{v}$ globoko razdeljeni povojni Bosni in Hercegovini. Toda mednarodni klici k spravi, osrednjemu cilju mednarodne skupnosti, so imeli pogosto drugačene, nepričakovane učinke, saj so v veliki meri neozaveščeno podpihovali nasprotujoče si interpretacije usodnega dogodka ter $v$ atentat vključenih zgodovinskih 
osebnosti, pri čemer je izstopal zlasti član Mlade Bosne in nekdanji jugoslovanski heroj - Gavrilo Princip.

Princip je sicer veljal za kontroverzno osebnost že od začetka dvajsetega stoletja (glej Donia 2014; Harrington 2014, 2015; Katz 2014; Lukec 2016; Miller 2014; Petrović-Ziemer 2015; Vervaet 2016). Kot ugotavlja Robert Donia, je ta pogosto deloval kot »tabula rasa, na katerega so drugi projicirali svoje interpretacije « (2014: 57). Politična instrumentalizacija Gavrila Principa in Mlade Bosne se je v času vojne le še okrepila, v postdaytonski državi pa so se tudi z obeleževanjem stote obletnice poglabljali spori, ki so povezani z identitetnimi politikami ter politizacijo preteklosti. Toda četudi spori niso bili omejeni zgolj na etnonacionalne konflikte, so ti $\mathrm{v}$ celoti okupirali znanstveno, politično in medijsko pozornost. Tudi znanstvene analize se torej omejujejo zlasti na uradne naracije dveh bosansko-hercegovskih entitet, in sicer Federacije Bosne in Hercegovine ter Republike Srbske. Tako številni opazovalci slovesnosti ob stoti obletnici izpostavljajo predvsem dominantne, docela nasprotujoče si interpretacije Gavrila Principa in atentata, se pravi dve različici nacionalizirane »uporabne preteklosti« (Wertsch 2012). Srbsko prebivalstvo države naj bi po dominantnih interpretacijah Principa upodabljalo izključno kot $\gg$ nacionalnega «, srbskega heroja, medtem ko naj bi ga Bošnjaki in Hrvati opisovali kot »terorista « in zločinca. Bolj balansirana vrednotenja, ki se odmikajo od nacionalizirane interpretacije Principa, raziskovalcev večinoma ne pritegnejo (za izjeme glej Donia 2015; Lukec 2016; Vervaet 2016). Gre za posledico prevlade metodološkega nacionalizma v raziskavah postjugoslovanskega prostora, ki še vedno ključno vpliva tudi na dojemanje procesov spominjanja in pozabljanja $\mathrm{v}$ povojnem kontekstu (glej Bartulović 2013; Jansen 2007).

Namen članka je torej preizprašati simplificirano razumevanje spominjanja v sodobni Bosni in Hercegovini, in sicer z upoštevanjem recentnih diskusij o dinamičnosti spomina v postkonfliktnih družbah. Ker spominjanje na sarajevski atentat ni zamejeno s statičnimi spomeniki in uradnimi naracijami, temveč poteka skozi »interakcijo različnih medijev /.../ in akterjev spomina « (Varvaet 2016: 552), članek obravnava predvsem manj očitne sfere produkcije in reprodukcije spomina na atentat. $\mathrm{V}$ ospredju so turistične rabe Principa, torej procesi njegove komodifikacije in reinterpretacije, (v katerih smo priča tudi prevrednotenju umorjenega habsburškega para), ki jih je bilo mogoče opazovati ob obeležitvi stote obletnice začetka velike vojne v Federaciji Bosne in Hercegovine. Članek prav tako razgrinja lokalne odzive na dominantne nacionalne naracije in komemoracije dogodka ter 
izpostavi družbeno-kritične odzive prebivalcev Bosne in Hercegovine, ki se oblikujejo v sodobnem postkonfliktnem daytonskem »čakanju « (glej Bartulović 2013; Jansen 2015). Namreč soočanje prebivalstva $s$ trajajočo negotovostjo ponuja pomembno motivacijo in platformo za pogajanje $\mathrm{z}$ uradnimi različicami zgodovine, kar je ključnega pomena za premislek o razumevanju procesov spominjanja na območju nekdanje Jugoslavije.

Članek temelji na terenski raziskavi, ki sem jo v več krajših obiskih Sarajeva opravljala med letoma 2014 in 2018. S pomočjo polstrukturiranih intervjujev ter analize različnega promocijskega in izobraževalnega gradiva, ki je bilo namenjeno zlasti mednarodni javnosti kot del turistične promocije, članek prikazuje komodifikacijo ter politično in turistično (iz)rabo sarajevskega atentata. Po uvodni predstavitvi osrednjih dogodkov, ki so obeležili stoto obletnico začetka prve svetovne vojne $\mathrm{v}$ Bosni in Hercegovini, obravnavam transformacije percepcij Gavrila Principa in njegovih žrtev v turističnih naracijah Federacije Bosne in Hercegovine, pri čemer razkrivam tako prelome kot kontinuitete, ki vztrajajo navkljub ali ravno zaradi radikalne bosansko-hercegovske družbene transformacije. Drugi del članka obravnava dinamično naravo spominjanja v Bosni in Hercegovini. Slednjo analiziram skozi etnografsko raziskavo različnih naracij, ki kritično reflektirajo dominantne, politične reprezentacije Principa in različna stališča o uradnem obeleževanju stoletnice velike vojne. Med drugim članek prikazuje »spominske tenzije « kot prakse konstrukcije alternativne »uporabne « preteklosti. Te omogočajo mobilizacijo zgodovinske zapuščine pri oblikovanju politike upanja tudi za tiste segmente bosansko-hercegovskega prebivalstva, ki ne zmorejo sprejeti vsiljene amnezije in dominantnih nacionalnih podob preteklosti.

\section{POLITIČNE MANIFESTACIJE IN NJIHOVE REFLEKSIJE}

Navkljub recentni kritiki znanstvenikov, ki so opozorili, da vztrajno osredotočanje na usodne sarajevske strele prikriva realnost prve svetovne vojne ter diskusijo preusmerja $\mathrm{v}$ politične in ideološke spore, so stoto obletnico sarajevskega atentata obeležili pompozno. Večino prireditev, ki so potekale med letoma 2013 in 2014, predvsem v Sarajevu, pa tudi v drugih bosansko-hercegovskih mestih, so organizirale ter financirale različne, večinoma tuje (politične) organizacije. V Federaciji Bosne in Hercegovine lahko govorimo zlasti o interesu 
različnih držav EU ter težnjah mednarodne skupnosti po slavljenju evropske sprave, medtem ko je prireditve na območju Republike Srbske z drugačnimi razlogi podpirla zlasti Republika Srbija (glej Hasanbegović 2015; Kamberović 2014). ${ }^{\mathbf{1}}$ Kulturni spektakli, izobraževalni in športni dogodki (med katerimi je bila, na primer, tudi sarajevska kolesarska tekma - Grand Prix označena kot »dirka za mir «, ki je bila organizirana pod pokroviteljstvom Tour de France) so bili namenjeni raznoliki publiki, organizirane pa so bile tudi mnoge znanstvene konference, ki so pritegnile predvsem tuje raziskovalce. ${ }^{2}$ Toda akademski dogodki, namenjeni problematizaciji persistentne politizacije spomina na atentat, so s političnimi nestrinjanji obtežili tudi znanstveno razpravo. Tako Husnija Kamberović (2014) v svoji analizi komemoracij dogodka zapiše, da je veleposlaništvo Republike Francije v Sarajevu odigralo ključno vlogo pri problematizaciji znanstvenih razprav, saj je nasprotovalo organizaciji konference na Zgodovinskem inštitutu v Sarajevu, na kateri so sodelovale številne evropske znanstvene institucije. Tudi osamljeni francoski zgodovinarji so se pridužili nekaterim srbskim medijem, ki so konferenco z naslovom The Great War: Regional Approaches and Global Context (18-21. junija 2014) označili za »prohabsburško «, organizatorjem - ki so sicer trdili, da je namen konference znanstvena razprava o dediščini Velike vojne - pa očitali, po mnenju Kamberovića, intenco po prelaganju krivde za začetek vojne na $\gg$ Srbijo, Francijo in, posredno, Rusijo « (Kamberović 2014: 11-2). Torej, tudi znanstvena skupnost, ki se je sicer na deklarativni ravni opredelila proti redukcionistični interpretaciji Velike vojne in sarajevskega atentata, ni uspela ubežati konfliktom, prav tako pa so se tudi znanstveniki zapletli v politično vsiljeno vprašanje, ki zasleduje pravo $\gg$ naravo $\ll$, motivacijo in cilje Gavrila Principa. Prevrednotenja dominantnih protagonistov sarajevskega atentata so namreč preplavila javno debato in v veliki meri zasenčila druga, ključna vprašanja o začetkih velike vojne.

Medijska poročila, ne nazadnje tudi znanstvene obravnave komemoracije stoletnice, so ponujala enodimenzionalno analizo dogodkov, pri čemer so se osredinjala zlasti na konfliktne vzporedne dogodke, ki so potekali v Sarajevu in Višegradu. Dve nasprotujoči si komemoraciji v resnici osvetljujeta politične spore med bosansko-hercegovskimi državljani in moč etnonacionalnih razkolov, vendar kažeta 2014; Harrington 2014, 2015.

2 Nazif Hasanbegović ugotavlja, da je v Sarajevu junija 2014 potekalo vsaj pet znanstvenih konferenc o dediščini atentata in prve svetovne vojne (2015: 269). 


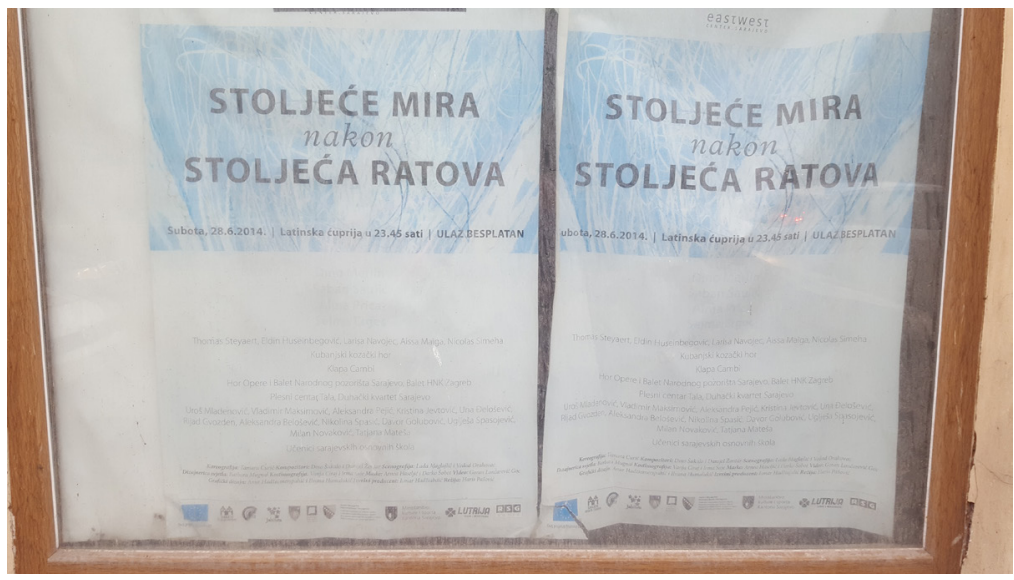

Slika 1: Zaprašeni plakati, ki vabijo na mega- spektakel z naslovom Stoletje miru po stoletju vojn, Sarajevo, marec 2019 (foto: Alenka Bartulović).

predvsem na razklanost političnih elit, ki se s pomočjo problematične daytonske ureditve ohranjajo na oblasti. Ne eni strani je tako v Sarajevu v mestni hiši, znani Vijećnici, ki jo je zgradila avstro-ogrska oblast $\mathrm{v}$ času okupacije Bosne in Hercegovine, potekal tako imenovani megaspektakel z naslovom Stoletje miru po stoletju vojn (A Century of Peace After the Century of Wars). Prireditev je gostil avstrijski predsednik Heinz Fischer, del te pa je bil tudi koncert dunajskega filharmoničnega orkestra. Druga slavnostna komemoracija, poimenovana Uporniški angeli (The Rebel Angels), je potekala v Republiki Srbski ob odprtju Andrićgrada, projekta znamenitega režiserja Emirja Kusturice v Višegradu. Novi srbski lieu de mémoire so namreč odprli na Vidovdan 2014 v navzočnosti številnih srbskih akademikov in politikov, med katerimi sta vidno mesto zasedala nekdanji predsednik Republike Srbske Milorad Dodik in srbski premier Aleksandar Vučić, ki je zavrnil povabilo na osrednji dogodek v Sarajevu. ${ }^{3} \mathrm{~V}$ sarajevskih slavnostnih komemoracijah so organizatorji poudarjali zlasti mir in evropsko enotnost, pri čemer so se precej nespretno izogibali omembi Gavrila Principa. Nasprotno pa so dogodki, ki so potekali v Republiki Srbski, potiskali mladega atentatorja v ospredje naracije. Tako je, denimo, Kusturica v Višegradu ob spominski slovesnosti odkril mozaik Mladi Bosni in Principu ter potrdil svoje iskreno navdušenje nad nekdanjim jugoslovanskim »demonizacijo « Srbov (glej Harrington 2015: 568), kar naj bi izpričevala tabla na mestni hiši, kjer so Srbi, ki so porušili zgradbo med obstreljevanjem mesta, označeni kot $\gg$ srbski kriminalci«. 
herojem, ki ga je izpričal tudi ob odkritju spomenika Principu v Tovariševu, v Vojvodini aprila 2014, ko se mu je s poljubi zahvalil za obstoj moderne Srbije (sic!) (Vervaet 2016: 552-53). V vzhodnem delu Sarajeva, v Republiki Srbski, so prav tako počastili spomin na Principa $s$ postavitvijo grandioznega bronastega spomenika, pri čemer so člana Mlade Bosne označili kot srbskega junaka in sočasno zanikali njegovo jugoslovanstvo (Harrington 2015: 568). Srbska apropriacija nekdanjega jugoslovanskega heroja je le nadaljevanje dolgega, vendar kompleksnega procesa, ki mu je moč slediti vse od začetka dvajsetega stoletja (glej Harrington 2014; Miller 2014). Na tem mestu velja opozoriti, da se je nacionalna karakterizacija Principa kot borca za izključno $\gg$ srbsko stvar « intenzivirala v 1990-ih letih. ${ }^{4}$

Nekonsistentno izogibanje Gavrilu Principu v Federaciji Bosne in Hercegovine ter prenovljena transformacija Principa v registru srbskega nacionalizma sta pritegnila medijsko pozornost; $v$ duhu sodobnega iskanja senzacionalističnih novic ne preseneča, da so poročila o obeleževanju stoletnice $v$ Bosni in Hercegovini obsesivno prikazovala konflikte, povezane z nasprotujočimi reinterpretacijami Gavrila Principa. Preprosta medijska analiza razkriva trdoživost balkanistične optike in nezadržno privlačnost »etničnega « nacionalizma in z njim povezanega antagonizma na Balkanu. Mediji so slepo sledili logiki »spravnega « diskurza in s pomočjo različnih naracij o Principu dokazovali, da je sprava med pripadniki različnih narodov še vedno nemogoča oziroma v povojih (glej Burns 2014)..$^{\mathbf{5}}$ Prav tako so se znova dotaknili stališča, da v Bosni in Hercegovini obstajata zgolj dve, povsem nasprotujoči si interpretaciji Principa, ki stojita na diametralno nasprotnih koncih: ena Principa vidi zgolj v vlogi heroja, druga ga označuje kot terorista. Analiza različnih medijskih poročil tako razkriva nemoteno koherenco naracij kot tudi dominacijo interpretativnega okvirja metodološkega nacionalizma, kjer je pozornost usmerjena izključno na etnonacionalne razkole. Tovrstni vidik predvideva tudi homogenizacijo nacionalnih skupnosti skozi procese sinhronizacije spominov, ob tem pa se zanemarjajo dognanja vrste antropoloških študij, ki izpričujejo kompleksnost in nekoherentnost spominjanja v postjugoslovanskem prostoru (glej Belaj in Škrbić-Alempijević 2014; Jansen

Med vojno so v srbski vojski podeljevali odlikovanja za pogum, ki so nosila Principovo ime (Kamberović 2014: 10). Prav tako so takoj po vojni številni srbski intelektualci, javne osebnosti in politiki, ki so med vojno ostali v Sarajevu, doživljali grožnje s strani teroristične skupine, ki se je poimenovala Srbska osvobodilna fronta Gavrila Principa (Alibečirević-Lunjo 2013).

5 http://www.nytimes.com/2014/06/27/world/europe/in-sarajevo-gavrilo-princip-setoff-world-war-i.html?_r=0; dostopno 5. aprila 2017. 
2007; Beronja in Vervaet 2016). Zato ne preseneča, da je dominantni medijski in delno tudi znanstveni diskurz o obeleževanju obletnice docela spregledal razmeroma majhen, pa vendar glasen protest, ki je potekal v Sarajevu, nasproti Vijećnice, kjer so se ob osrednji prireditvi zbrali protestniki, ki so nosili Principove maske. Preprosta razlaga, ki bi ustrezala optiki metodološkega nacionalizma, bi lahko protestnike označila kot nezadovoljne člane srbske skupnosti v Sarajevu, ki nasprotuje preobrazbi jugoslovanske naracije o atentatu v Federaciji Bosne in Hercegovine. Toda razlago za njihovo zavračanje obeleževanja stoletnice $\mathrm{z} \gg$ megaspektaklom « je, kot ugotavljam v zaključku, treba iskati drugje, predvsem pa onkraj logike simplificiranega razumevanja Bosne in Hercegovine kot države, ki jo zaznamujejo izključno na nacionalni osnovi utemeljena nasprotja.

\section{KRATKA ZGODOVINA PRINCIPOVEGA (PRE)VREDNOTENJA}

Obdobje po drugi svetovni vojni označuje kompleksna »glorifikacija « Gavrila Principa, saj je ta skupaj s partizani šele v povojni socialistični Jugoslaviji prikazan kot osvoboditelj in jugoslovanski heroj (Hajdarpašić 2015: 159). Kot ugotavlja Paul Miller, so takrat tudi »navadni « podporniki jugoslovanstva začeli »konstruirati sarajevski atentat kot zgodbo upiranja in osvoboditve «, ki je presegala partikularnost etničnih, nacionalnih, religioznih identitet (2014: 4). Toda prav politična podpora pri konstruiranju novih uradnih naracij je bila ključna v procesu Principovega prevrednotenja (glej Donia 2014; Harrington 2015). Memoralizacije in komemoracije Principa in Mlade Bosne so bile v veliki meri politizirane; dominantne interpretacije so člane organizacije poveličevale kot predhodnike partizanskega antifašističnega boja, ki je ustavil nemške ekspanzionistične tendence in omogočil oblikovanje jugoslovanskega bratstva in enotnosti. Številne mestne ulice in šole $\mathrm{v}$ Jugoslaviji so bile poimenovane po Gavrilu Principu in članih Mlade Bosne, Sarajevo, kot prizorišče atentata, pa se je uveljavilo kot »epicenter « »Principovega kulta « (Miller 2014: 23-4). To se je odražalo tudi v sarajevskem mestnem tkivu, najočitneje na pomembnih krajih spomina, ki so bili ponovno ovrednoteni in rekonstruirani. $\mathrm{V}$ tem procesu je ključna transformacija znamenitega sarajevskega vogala $\mathrm{v}$ najpomembnejši prostor spomina, kjer so 27. junija 1953 odprli Muzej Mlade Bosne. Z rdečim zapisom v cirilici so jasno označili pomen sarajevskega atentata za jugoslovansko zgodovino in uresničitev stoletnih teženj jugoslovanskih narodov po 
svobodi. Magična privlačnost kraja atentata se je izdatno povečala $s$ postavitvijo »Principovih stopinj « na mesto, od koder naj bi izstrelil usodne strele. ${ }^{6}$ Stopinje, ki v resnici niso bile Principove, so nezadržno privlačile tako turiste kot domačine, saj so obiskovalce vabile, da se $s$ poistovetenjem $\mathrm{z}$ atentatorjem vključijo v zgodovinsko prelomni dogodek. Vendar raziskovalci opažajo, da je heroizacija Principovega dejanja že v 1960-ih letih počasi, vendar vztrajno začela bledeti. Ob petdeseti obletnici sarajevskega atentata so se nekateri visoki politiki, vključno s predsednikom Josipom Brozom Titom, začeli distancirati od uradnih praznovanj v Sarajevu (Miller 2014: 31). V 1970-ih letih je jugoslovanska oblast Principa pretvorila v slavno osebnost, kar naj bi omogočilo odmik od ideoloških karakterizacij (glej Donia 2014). V 1980-ih letih pa so osamljeni in poprej marginalizirani glasovi začeli že javno oporekati uradni jugoslovanski naraciji o dogodku, »ki je pretresel svet «, kar je močno vplivalo tudi na upodobitev osrednjih protagonistov. ${ }^{7}$ Zato so navkljub zanimanju zunanjih obiskovalcev za slovesne obeležitve usodnega atentata glasne proslave počasi izginile (Harrington 2014: 131). Torej dolga pot počasne transformacije Principa, Mlade Bosne in sarajevskega atentata kaže, da reinterpretacije dogodka, ki se je zgodil v 1990-ih letih, ni mogoče prikazati kot enostavnega ter hipnega reza. Kljub temu pa je očitno, da je vojna, vključno z obdobjem povojne rekonstrukcije, prispevala nove motivacije za pospešitev procesa revalorizacije. Tik pred vojno v Bosni in Hercegovini so izrabe Principa, zlasti med bosanskimi Srbi, ${ }^{8}$ postale vse bolj očitne, kar je imelo za posledico tudi okrepitev debat med ostalimi državljani Bosne in Hercegovine, predvsem med politično in intelektualno elito. Med vojno so srbske sile uspešno zlorabljale Principovo ime za vojaško motivacijo, kar je mnoge Sarajevčane vodilo, da sprejmejo neutemeljene povezave med Principom in srbskimi napadalci, ki naj bi enako zagnano zastopali idejo Velike Srbije. ${ }^{9}$ Zato je za večino Princip simboliziral neusahljive srbske teritorialne apetite (glej tudi Miller 2014: 35; Kamberović 2014: 9). V novem kontekstu, ki je podpiral

6 V resnici je odtis stopinj prispeval mladi kipar Mirko Ostojić (Harrington 2015: 579).

7 Proces »demitologizacije « Principa naj bi v Bosni in Hercegovini začel zgodovinar Mustafa Imamović, ki je že leta 1970 na konferenci predstavil prispevek, v katerem je po mnenju Kamberovića razkril zmote pri dojemanju Principa kot borca za »jugoslovansko združevanje « (Kamberović 2014: 9).

8 Miller sicer trdi, da so bili jugoslovanski zgodovinski učbeniki precej nevtralni pri opisovanju atentata in Gavrila Principa ter da se je prava heroizacija v šolskih učnih načrtih začela v Srbiji šele konec 1980-th let (2014: 23).

9 Debata o naravi Principovega nacionalizma in nacionalizma Mlade Bosne še ni zaključena, raziskovalci pogosto opozarjajo tudi na zabrisano mejo med srbskim in jugoslovanskim nacionalizmom (Aleksov 2014; Vervaet 2016: 556). 
izbris jugoslovanskega kolektivnega spomina, tudi na Principa in sarajevski atentat, je bilo precej preprostejše razglasiti Principovo dejanje za brutalen terorističen napad. Tako je predrugačena podoba nekdanjega skupnega heroja ${ }^{\mathbf{1 0}}$ ponudila hrvaškim vojaškim silam v Bosni in Hercegovini odličen izgovor za uničenje Principovega muzeja v njegovi rojstni vasi, v Obljaju (Miller 2014: 35). Po nekaterih teorijah so tudi znamenite Principove stopinje, »ikone atentata « (Miller 2014: 215), končale v reki Miljacki, kamor naj bi jih odvrgli pripadniki bosansko-hercegovske vojske. ${ }^{\mathbf{1 1}} \mathrm{V}$ tem pogledu je Princip v času razpada Jugoslavije in brutalnega etničnega čiščenja vsaj na prvi pogled izginil tudi iz pozitivnih kolektivnih spominov Hrvatov in Bošnjakov.

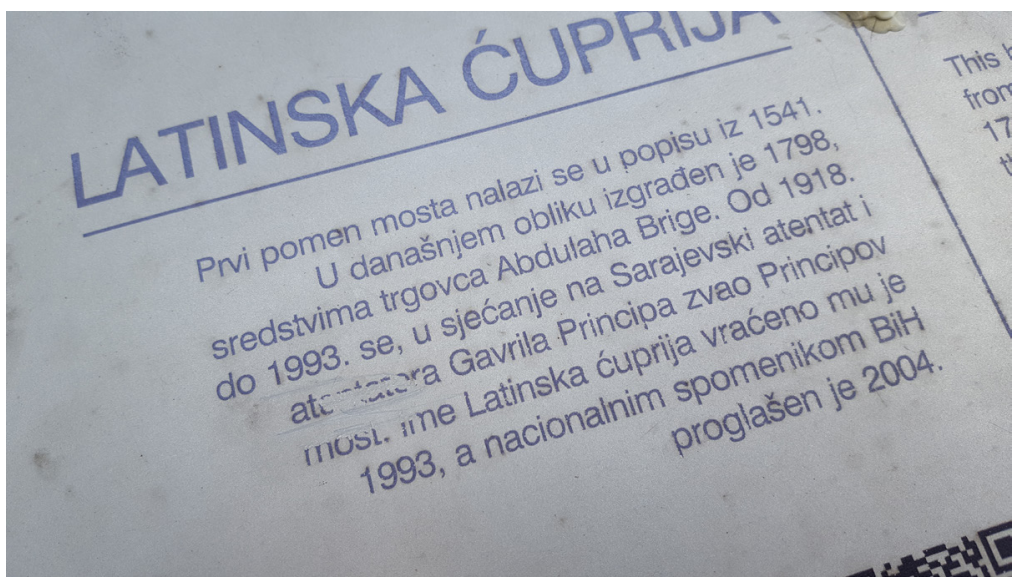

Slika 2: Tabla, ki označuje nekdanji Principov most, Sarajevo, april 2018 (foto: Alenka Bartulović).

\section{TURISTIČNE RABE PRINCIPA}

Navkljub transparentnemu prevrednotenju nekdanjih jugoslovanskih reprezentacij atentata sodobne interpretacije dogodka $\mathrm{v}$ turističnih naracijah v Federaciji Bosne in Hercegovine niso povsem enoznačne. Diskurzivna analiza turističnih brošur, zemljevidov, vodičev, spremljevalnih tekstov ter informativnih knjižic, napisanih večinoma za

10 Homogenizacija kolektivnega spomina na atentat v nekdanji Jugoslaviji se v resnici ni nikoli zgodila.

11 Obstajata dve, nasprotujoči si teoriji o usodi stopinj. Po prvi teoriji naj bi stopinje odstranili vojaki bosansko-hercegovske vojske, druga pa zagotavlja, do so bile stopinje uničene v času obstreljevanja Sarajeva (Kamberović 2014: 9-10). 
splošno javnost $\mathrm{v}$ angleškem jeziku $s$ strani zgodovinarjev, kustosov in tudi amaterskih zgodovinarjev, ${ }^{\mathbf{1 2}}$ zelo jasno ponazarja rez z jugoslovansko percepcijo Principa in atentata. Povedno ilustracijo ponuja primerjava $\mathrm{z}$ jugoslovanskimi turističnimi priročniki. Tako, na primer, v knjigi Guidebook to Sarajevo (Čelić 1983) beremo, da je Mlada Bosna združevala Srbe, Muslimane in Hrvate, študente, »delavce, kmete, učitelje in trgovce «, ki so se bojevali proti tuji dominaciji in izkoriščanju. Avtor poudarja tudi mladobosansko projugoslovansko politično usmeritev, izpostavlja pa tudi podatek, da je avstro-ogrska monarhija izrabila sarajevski atentat kot izgovor za napoved vojne Srbiji (1983: 15). Ker je bila knjiga napisana že v 1980-ih letih, v njej ne najdemo odkritega navduševanja nad dijakom Gavrilom Principom, vendar pa je tudi sočutje do umorjenega habsburškega para povsem odsotno. Nasprotno večina analiziranega gradiva, objavljenega med letoma 2014 in 2015, nespretno prezira mladega atentatorja Principa ter Mlado Bosno, bralce pa poziva zlasti k etičnosti do žrtev, pri čemer se poslužujejo tudi nepotrjenih informacij. Tako med drugim ugotavljajo in poudarjajo, da je bila Žofie Chotková ob smrti noseča. Zgodovinar Vahidin Preljević in urednik Muamer Spahić v svoji knjižici z naslovom Sarajevo Assassination (2015) podrobno opisujeta prepovedano ljubezen med Francem Ferdinandom in njegovo izvoljenko iz obubožane češke aristokratske družine (2015: 47-8). Med drugim poudarjata tudi tragično ironijo usode, ki je hotela, da ju je ravno prva uradna skupna pot znotraj meja monarhije vodila v Sarajevo, kjer sta 28. junija 1914 podlegla pod Principovimi streli. Avtorja hvalita tudi pacifistično orientacijo prestolonaslednika in njegovo prizadevanje po ohranjanju celovitosti bosanskega ozemlja (2015: 43). Ta poudarek o nasprotovanju delitve Bosne je namreč zelo pomemben, zlasti če ga prebiramo v času, $\mathrm{v}$ katerem še vedno dominirajo ambicije po dokončnem razkosanju bosansko-hercegovskega ozemlja. Čeprav pacifistične plati prestolonaslednika v drugem analiziranem gradivu ne omenjajo, je vendar jasno, da se je percepcija umorjenega para v enaindvajsetem stoletju v dominantnih naracijah zelo spremenila. Ob uradnem obeleževanju stote obletnice atentata so tako obiskovalce dogodka prvič povabili, da se identificirajo z žrtvama. Tako so bili obiskovalci dogodka vabljeni, da namesto v Principove stopinje vstopijo v repliko 2014 in 2015. Gre za gradivo, ki je večinoma napisano za angleško govorečo javnost, ki ni bila nikoli docela seznanjena ali navdušena s slavljenjem Principa in Mlade Bosne v Jugoslaviji (glej Miller 2014). Izbrano gradivo pa zelo jasno reflektira dominantno, dovoljeno naracijo $v$ javni politiki spominjanja v Federaciji Bosne in Hercegovine. 
avtomobila, v katerem sta svojo smrt dočakala Franc Ferdinand in Žofie Chotek. Avtomobil je bil parkiran pred nekdanjim Muzejem Mlade Bosne, ki se je po letu 1992 preimenoval v Muzej Sarajeva 1878-1918, v katerem se je vidno spremenila tudi muzejska postavitev, ki naj bi bila po nekaterih mnenjih sicer bolj odprta za različne interpretacije (Harrington 2015: 582), po drugih pa predstavlja popolno deheroizacijo oziroma demonizacijo nekdanjih junakov (Miller 2014: 39). ${ }^{13} \mathrm{~V}$ razstavi zasedata prominentno mesto lutki umorjenega para v naravni velikosti, kar ustreza novemu konceptu razstave, ki predstavlja zlasti avstro-ogrsko okupacijo Bosne in Hercegovine, v kateri le na kratko omenjajo sarajevski atentat. Kustosi so ob stoti obletnici atentata postavili tudi dve informativni tabli, in sicer eno na začetek nekdanjega Principovega mostu (danes Latinske ćuprije), kjer je nekoč stal spomenik, posvečen umorjenemu paru, drugo pa na mesto »Principovih stopinj « (Kamberović 2014: 14). Če so obiskovalci tokrat lahko pozirali v avtu, oblečeni tudi v kostume, ki so spominjali na oblačilni videz prestolonasledniškega para (Donia 2014: 72), uradnega povabila v Principove »čevlje « tokrat ni bilo. Primeren način komemoracije tragičnega dogodka je bil torej izenačen z identifikacijo z žrtvami, ne atentatorjem, kar potrjuje tudi podatek, da po vojni niso bile nikoli več na prvotnem mestu, navkljub ostrim pogajanjem leta 2003 (Kamberović 2014: 10). Toda razprava o vračanju Principovih stopinj na znameniti sarajevski vogal še vedno ni v celoti poniknila, saj je leta 2014 Samir Kaplan, takratni minister za kulturo in šport Federacije Bosne in Hercegovine, za hrvaški Večernji list izjavil, da sam podpira rekonstrukcijo stopinj, pa tudi spomenika Francu Ferdinandu in njegovi soprogi. Rekonstrukcijo spomenikov je pojasnil kot ključno potezo ustreznega turističnega trženja sarajevskega atentata (Medunjanin 2014).${ }^{\mathbf{1 4}}$ Pomembno je tudi omeniti, da odlitek $\gg$ Principovih stopinj « sicer stoji v muzeju, ob vhodu, vendar to ne omogoča enake izkušnje, kot so jo imeli obiskovalci v času Jugoslavije, ko so lahko dobesedno »vstopili v Principove čevlje «.

Sodobne reinterpretacije atentata kažejo predvsem na močno poistovetenje $\mathrm{z}$ aristokratskim parom. Ti napori se združujejo z odprtim slavljenjem modernizacije in »evropeizacije « Bosne in Hercegovine pod avstro-ogrsko vladavino, prav tako pa tudi s prevrednotenjem

Po mnenju Millerja razstava idealistično prikazuje obdobje avstro-ogrske vladavine, ki naj bi državo pripeljala bližje evropski prihodnosti. Principovi streli so v tej naraciji torej označeni kot zaviralni pri razvoju države, saj so ustavili bosansko-hercegovsko evropsko integracijo in modernizacijo (Miller 2014: 39-40).

14 http://www.vecernji.ba/principove-stope-i-spomenik-ferdinandu-privukli-bituriste-915939, dostopno 10. maja 2017. 
Gavrila Principa. ${ }^{\mathbf{1 5}}$ Poudarjanje pozitivnih plati imperialne nadvlade, ki se je v zadnjih dveh desetletjih v Federaciji vidno okrepila, ${ }^{\mathbf{1 6}}$ implicira drugačno razumevanje jugoslovanske preteklosti; tako je Jugoslavija prikazana kot projekt srbske ekspanzionistične politike, ki naj bi zavirala kulturni in ekonomski razvoj Bosne in Hercegovine. $S$ tovrstnim prevrednotenjem se vztrajno spreminja tudi percepcija življenja v nekdanji multinacionalni državi in sočasno zavračajo pozitivne plati jugoslovanske zapuščine (prim. npr. Beronja in Vervaet 2016; Jezernik 2015; Karačić, Banjeglav in Govedarica 2012; Petrović 2012; Potkonjak in Pletenac 2016). Govorimo torej o partikularni obliki avstronostalgije, ki predstavlja nekdanji imperij predvsem kot »urejeno državo « (glej Baskar 2007: 48). Tovrstni nostalgični spomini jasno odražajo splošno nezadovoljstvo z nedelujočo daytonsko Bosno in Hercegovino (glej npr. Bartulović 2013; Jansen 2015; Kurtović 2015) ter z zelo počasnim bosansko-hercegovskim premikanjem k EU. Bosansko-hercegovska turistična industrija se torej precej odkrito spogleduje $\mathrm{z}$ avstronostalgijo, kjer se romantizirana avstro-ogrska preteklost kaže kot alternativen ali vsaj uspešen model urejanja bosansko-hercegovske prihodnosti.
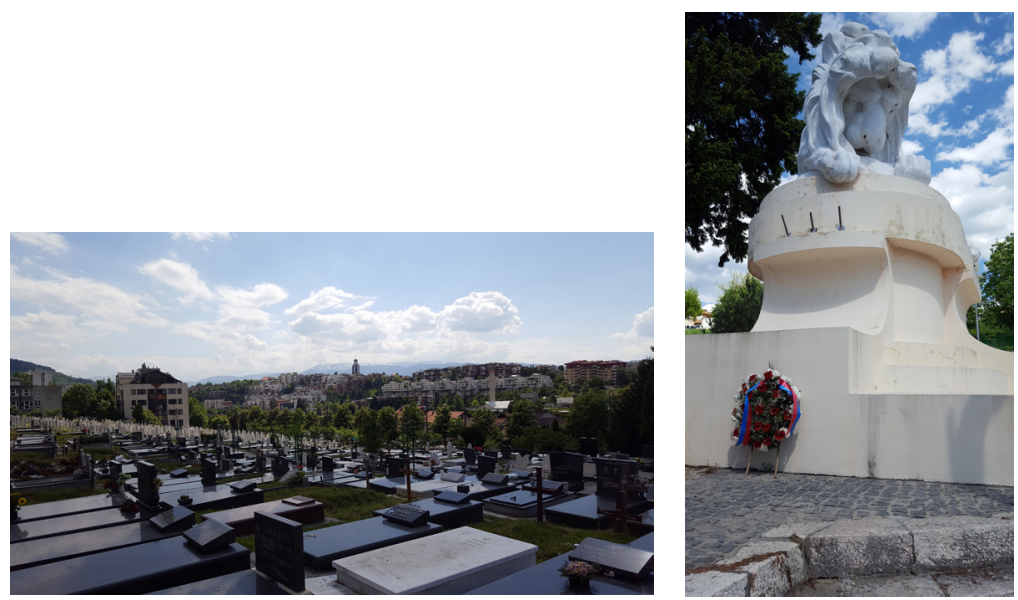

Slika 3: Pokopališče Lav in Spomenik avstroogrskim vojakov, kiparja Jozefa Urbanije, april 2018 (foto: Alenka Bartulović).

Kljub temu da je Avstrija odigrala ključno vlogo v komemoracijskih slovesnostih, njena vloga v medijih ni bila problematizirana enako kot dejavnosti Francije in francoskega veleposlaništva v Sarajevu. ga mnogi dojemali kot etnično nemško državo, je bilo zlasti pri izobraženi bosanskohercegovski muslimanski eliti mogoče opaziti drugačno, bolj pozitivno imaginacijo avstro-ogrske okupacije (Baskar 2007: 48; 54-5). 
Čeprav v javni percepciji prevladuje mnenje, da je v Federaciji Bosne in Hercegovine Princip predstavljen izključno kot srbski terorist, analiza gradiva kaže, da so spomini nanj tudi v tem delu Bosne in Hercegovine precej bolj neenotni. Tu predstavljam le dve dominantni, med seboj povezani percepciji Principa, ki na subtilen način krhata njegovo jugoslovansko heroizacijo, vendar hkrati spodkopavata simplificirane nacionalne karakterizacije atentatorja.

Princip je tako predstavljen kot problematičen, vzkipljiv, agresiven, a vendar tudi šibek dijak, ki je trpel zaradi tuberkuloze in družbene odtujitve. $\mathrm{V}$ turističnih naracijah avtorji omenjajo njegove frustracije $\mathrm{z}$ lastnim telesom, saj mu je krhkost onemogočila udeležbo v balkanskih vojnah. Nezadovoljstvo naj bi Principa vodilo k iskanju drugih možnosti za samouresničitev. Analizirano gradivo poudarja tudi Principovo sovraštvo do čaršije, ${ }^{\mathbf{1 7}} \mathrm{ki}$ ga pisci argumentirajo z epizodo srečanja z Muslimani v hotelu ob njegovi preselitvi iz Obljaja v Sarajevo, ko je kot trinajstletni deček domnevno nasprotoval ideji, da bi spal skupaj $s \gg$ Turki « (Preljević in Spahić 2015: 52). Poudarjanje Principovega šibkega telesa in psihičnega neravnovesja je mogoče prebrati tudi kot neozaveščeno bosansko-hercegovsko opravičilo za tragične posledice velike vojne, v povojnem kontekstu pa tovrstni poudarki kažejo zlasti težnjo po reprezentaciji Principovega strela kot nepremišljenega dejanja dokaj osamljenega posameznika, ki je bil zaradi osebnih težav dovzeten za manipulacije in radikalne ideje nacionalističnih politikov. Tovrstna pojasnitev očitno uspešno zamegli kontekst samega atentata, pri čemer se povsem prezrejo Principove antikolonialistične ambicije in dejanski učinki avstro-ogrskega kolonializma na življenje bosansko-hercegovskega prebivalstva. Rekonceptualizacija Principa tako prinaša izbris kolektivne odgovornosti, zlasti med bosansko-hercegovskimi Hrvati in Bošnjaki. Oddaljevanje od »jugoslovanske « enotnosti se kaže tudi pri pripisovanju negativnega, orientalističnega odnosa Principa do bosanskih Muslimanov. Bralec naj bi skozi prebiranje gradiva dojel, da Princip svojih muslimanskih sonarodnjakov ni dojemal kot jugoslovanskih bratov, temveč so zanj bili predvsem Drugi. Tovrstna interpretacija radikalno briše jugoslovanske in tudi Principove težnje po združitvi južnih Slovanov.

Drug pomemben poudarek pri novih reprezentacijah Principa je osredinjanje na njegov ruralni izvor in družinsko tradicijo hajduštva. Ta vidik sicer ni povsem nov, saj Vladimir Dedijer v svoji znameniti 
knjigi Sarajevo 1914 (1966), ki je bila sicer okarakterizirana kot delo, ki idealizira atentat (Preljević in Spahić 2015: 79), prvič omenja besedno zvezo » agrarni terorizem «, ko govori o delovanju Mlade Bosne. Toda ta ocena se nanaša na agrarno vprašanje, ki je veljalo kot ključni razlog za nezadovoljstvo pripadnikov Mlade Bosne z avstro-ogrsko nadvlado (glej Varvaet 2016: 558; Dedijer 1966: 337). V povojnih letih se Principovo zanimanje za agrarna vprašanja reinterpretira. Ideja »agrarnega terorizma « se tako začne uporabljati precej drugače, na primer tudi z neizogibnim hashtagom na infografičnem zemljevidu Sarajeva iz leta 2014, ki ga je objavilo podjetje iz Londona z namenom »informiranja, izobraževanja in vizualnega komuniciranja dogodka eklektični mednarodni javnosti ${ }^{\mathbf{1 8}}$ Naslov zemljevida je izjemno poveden in ustreza konceptualizaciji Sarajeva kot nove turistične destinacije na zemljevidu tako imenovanega mračnega turizma: Sarajevo 1914-2014: 1 mesto, 3 vojne, 1 olimpijske igre = 1 lekcija.

Mnogi antropologi, ki so spremljali nasilen razpad Jugoslavije, so opažali poglobljene urbano-ruralne tenzije v urbanocentričnih diskurzih prebivalcev jugoslovanskih mest, ki so pogosto krivili $\gg$ nazadnjaške kmete « za nasilje, antagonizme in porast nacionalizma (glej npr. Armakolas 2007; Bartulović 2013; Jansen 2005; Stefansson 2007). Pogosta interpretacija vojne v 1990-ih letih je temeljila na idejah o urbicidu (nasilju, uperjenem proti mestu), kmečkem nerazumevanju mestnega življenja ali razlagah, ki so vojaški spopad opisovale kot » maščevanje podeželja « (Allcock 2009; Baskar 1999; Bougarel 1999). Med obleganjem Sarajeva je bilo v diskurzih Sarajevčanov pogosto odmikanje od nacionalizacije krivde, pri čemer so nemalokrat kot odgovorne krivce za vojno označevali $\gg$ ruralne primitivce «, ki se domnevno niso nikoli uspeli prilagoditi urbanemu načinu življenja in torej docela modernizirati. Posledično je tudi večina sarajevski atentat dojemala kot napad neizobraženih kmetov na civilizirano urbano okolje. Tudi nekateri raziskovalci Principove življenjske zgodbe izpostavljajo njegovo izkušnjo neprijetne migracije iz podeželskega v mestno okolje kot pomemben dejavnik za kopičenje jeze in nezadovoljstva, ki naj bi se kanaliziralo v usodnem strelu. Guido van Hengel tako trdi, da je Princip skupaj s prijatelji trpel zaradi neuresničene želje po »popolnem sprejetju v urbano skupnost « (2014: 93); ${ }^{\mathbf{1 9}}$ kljub temu pa je zavrnil Dedijerjevo karak- 
terizacijo pripadnikov Mlade Bosne kot $\gg$ primitivnih upornikov«, saj je Principa označil za »modernega aktivista «, čigar ideje so se sicer oblikovale $\mathrm{v}$ specifičnem $\gg$ medprostoru gostiteljskega mesta « (van Hengel 2014: 96). Skratka, politična korektnost v kombinaciji $\mathrm{z}$ močjo urbano-ruralnih dihotomij v Bosni in Hercegovini je pripisala radikalizacijo Principa njegovi trmi, nefleksibilnosti in težavam $\mathrm{z}$ asmilacijo, s katero se je soočal kot podeželski mladostnik. Navduševanje nad srbskim nacionalističnim ekspanzionizmom ali jugoslovanstvom je iz turističnih naracij izbrisano. Tudi njegove druge karakterne lastnosti in politične težnje so večinoma zamolčane. Gradivo ne omenja njegove inteligentnosti, relativne zrelosti in načitanosti, ki ga je povezovala s širšim evropskim mladinskim gibanjem. Prav tako so podatki o boju za boljše življenjske pogoje, družbeno enakost in svobodo izpuščeni, opazno pa je tudi strateško izogibanje omembe Principovega idealiziranega jugoslovanstva, (ki je bilo sicer med pripadniki Mlade Bosne razumljeno precej različno), ateizma in antiklerikalnih stališč (Varvaet 2016: 546, 557; glej tudi Aleksov 2014; Dedijer 1966; van Hengel 2014). Četudi so tovrstne ideje o Principu ostale zamolčane v dominantnih naracijah, te karakteristike niso povsem izginile iz javnega diskurza.

\section{PRINCIP NA SARAJEVSKIH ULICAH}

Na sarajevskih ulicah, tudi med turističnimi delavci, lahko zasledimo raznolike percepcije nekdanjega jugoslovanskega heroja. Zaradi vsiljene nacionalne optike in zanimanja, usmerjenega izključno $\mathrm{v}$ uradne različice uporabne preteklosti, raznolikost obstoječih percepcij med prebivalci Sarajeva ni pritegnila znanstvene pozornosti, četudi se je občasno prebila v medijski prostor. Tako smo lahko, na primer, v oddaji televizijske hiše Al Jazeera z naslovom Kontekst: Gavrilo Princip - terorist ali heroj? (2014) opazovali razburjenega hrvaškega zgodovinarja, Iva Banca, ki se je z začudenjem odzval na rezultate krajšega poizvedovanja med Sarajevčani o percepciji Gavrila Principa. Prispevek je namreč razkril, da Principa večina vprašanih ocenjuje pozitivno. Banac je takšno vrednotenje Principa označil za skrb vzbujajoče, saj je podporo razumel kot odobravanje vojne in nasilja. Tudi mnogi moji sogovorniki v Sarajevu so delili mnenje svojih someščanov, vendar je treba poudariti, da niso slepo slavili Principovega dejanja in so bili v splošnem zelo previdni pri preprostem označevanju Principa, saj ga praviloma niso razglašali za heroja. $\mathrm{Na}$ krajšem ogledu enega od 
najuspešnejših sarajevskih hostlov, ki nosi ime Franca Ferdinanda, je mlajši receptor poudarjal, da se je izobraževal v sistemu, ki je Principa označeval za terorista, toda tovrstni šolski načrt pri njem le krepi nezaupanje v povojno bosansko-hercegovsko izobraževanje: $\gg / . . . / j a z$ (Principa, op. A. B.) ne vidim kot slabega. Tistega, kar te učijo v naših solah, ne moreš vzeti resno /.../, saj vemo, da gre večinoma za politiko in ne zgodovino. V tem smislu mogoče ta naš šolski sistem niti ni tako zelo slab, saj te prisili, da vse, česar te učijo, preveriš vsaj dvakrat «. V tematskem hostlu, ki ponuja namestitev v sobah, poimenovanih po ključnih zgodovinskih osebnostih in bitkah Velike vojne, so se zavedali, da obstaja priložnost za zapolnitev manjka v sarajevski turistični ponudbi. Zaradi dobrega koncepta je namreč hostel postal medijsko zanimiv in tudi prepoznaven $\mathrm{v}$ mestu, ki je $\mathrm{v}$ zadnjem desetletju postal zasičen $\mathrm{z}$ namestitvami in prenočišči. Toda nacionalne in entitetske turistične agencije še vedno kažejo precejšnjo zadržanost, ko gre za promocijo sarajevskega atentata kot ene od najbolj relevantnih turističnih znamenitosti mesta, četudi vsa standardna turistična vodenja po mestu vključujejo mesto atentata kot ključno točko postanka. V pogovoru $s$ turističnimi vodniki in delavci v turizmu je bilo vendar moč zaznati pomislek, da bi aktivno oglaševanje sarajevskega atentata kot tudi izpostavljanje lastne interpretacije dogodka vodilo $\mathrm{k}$ težavam. Zato so se v splošnem raje osredinjali na prezentacijo zadnje vojne, svojo odločitev pa so upravičevali zlasti z (domnevno) večjim zanimanjem za nedavne dogodke. Tudi interpretacija vojne v 1990-ih letih se je večini zdela precej preprostejša naloga. Obotavljanje pri trženju atentata je opazno tudi v skoraj popolni odsotnosti tematskih vodenih ogledov in spominkov, vezanih na usodni dogodek.

V resnici se zdi, da je komodifikacija Principa, tudi v turizmu, precej bolj prisotna $\mathrm{v}$ Srbiji kot $\mathrm{v}$ Bosni in Hercegovini (Velikonja 2018). Tega ni moč razumeti zgolj kot posledice nelagodja, ki ga prinaša temačni turizem (glej Johnston 2010). Kljub velikemu potencialu sarajevskega atentata je iskanje spominkov po mestu razkrilo, da je bilo turistom na voljo le nekaj izdelkov ob obletnici začetka Velike vojne (med drugim tudi v Muzeju Sarajeva), vendar so ti zaradi velikega zanimanja kmalu pošli. Četudi so lokalni obrtniki vešči v iskanju priložnosti za zaslužek, saj po navadi vzdržujejo širša večgeneracijska gospodinjstva, se niso aktivno vključili v izdelavo in prodajo izdelkov, ki bi bili vezani na atentat. Toda svojo odločitev pojasnjujejo predvsem s stanjem trga in ne z ideološkimi zadržki: »To nikogar ne zanima, samo politike, vendar oni ničesar ne kupujejo, samo čakajo na darila.« Kljub temu se nekateri s to oceno o nezainteresiranih turistih niso strinjali, zlasti redki posamezniki, ki so se odzvali na povpraševanje 
in priložnost, ki jo je ponudila obletnica. Tudi s pomočjo lastnih spominov na jugoslovansko interpretacijo Principa so obiskovalcem Sarajeva ponudili določene izdelke, ki obeležujejo pomemben dogodek. Tako je, na primer, prodajalka srednjih let, ki dela v majhni trgovini na sarajevski Baščaršiji, kjer pravzaprav ekskluzivno ponujajo različne izdelke s podobami Gavrila Principa in Franca Ferdinanda, komentirala odsotnost tovrstnih spominkov kot odsev bosanske lenobe, zanemarjanja preteklosti ter tudi podvrženosti politični manipulaciji, ki vključuje zgodovinski revizionizem. Glasno je obsojala tudi odsotnost kreativnosti in uvažanje poceni izdelkov iz Kitajske in Turčije, kajti po njenem slednji ne morejo predstavljati njenega rojstnega mesta: $\gg$ Ko pogledašspominke, ki se prodajajo na čaršiji in nasploh v Sarajevu, se zdi, kot da sviloprejke živijo na Trebeviću. ${ }^{\mathbf{2 0}}$ Sama prodaja izdelke ene od najbolj znanih bosansko-hercegovskih grafičnih oblikovalk, ki se je prvotno odločila za oblikovanje majhne serije platnenih torbic in bedžev z liki Principa in Franca Ferdinanda. Tako tuji kot domači turisti, se pravi turisti z območja nekdanje Jugoslavije, še ugotavlja, $\mathrm{z}$ veseljem kupujejo ponujene izdelke, vendar so tuji po navadi bolj naklonjeni podobi prestolonaslednika (tudi zaradi škotske glasbene skupine), medtem ko naj bi bili državljani nekdanjih jugoslovanskih republik zavezani Principu. Slednje je trgovka dojemala kot povsem samoumevno izbiro, saj je po njenem: »Enostavno, Gavrilo Princip je bil in je še vedno naš Che Guevara. «

Torej, kult Gavrila Principa še ni povsem izginil iz povojnega Sarajeva, čeprav je doživel specifične preobrazbe. V nasprotju s prevladujočimi selektivnimi interpretacijami, ki se osredinjajo zgolj na politično motivirane ocene Principa v sodobni Bosni in Hercegovini in se odmikajo od pasti metodološkega nacionalizma, je Robert Donia (2014) v svoji analizi transformacij Principa zatrdil, da je v zadnjih desetletjih dvajsetega stoletja postal globalna zvezda in popularno-kulturna ikona. $V$ tej reformulaciji se je spremenil $\mathrm{v}$ politično dvoumno osebnost, ki pa je vendar vplivala na tok zgodovine. Med drugim avtor predvideva, da bo nova, apolitizirana podoba Principa zagotovo nadživela vse ideološko navdihnjene reinterpretacije, ki v Bosni in Hercegovini spodbujajo konflikte in nerazumevanja (2014: 69). Toda finančne koristi, ki naj bi jih Princip kot popularno-kulturna osebnost prinašal v povojno Bosno in Hercegovino ter Sarajevo, so precej zanemarljive, predvsem pa precej manjše, kot so bile v nekdanji Jugoslaviji. Še danes pa je očitno, da preobrazba v popularno-kulturno ikono Principa ni 
odrešila njegove politične relevance, pravzaprav je nov, povojni kontekst njegovo vlogo in moč le še okrepil. Tako v sodobni Bosni in Hercegovini nekdanji atentator ni le odlično orodje v nacionalnih bitkah ter pomemben dejavnik pri argumentaciji močnejše etnonacionalne separacije, temveč postaja tudi del strategij boja za identitete in sentimente, ki so v svoji osnovi subverzivni in antinacionalistični.

\section{ZAKLJUČEK: DRUGA STRAN PRINCIPA}

V svojem znamenitem delu Imaginarni Balkan Maria Todorova ugotavlja, da je sarajevski atentat pomembno vplival na vrednotenje celotnega območja v evropski in svetovni imaginaciji. Principovi streli so izbrisali vse obstoječe ambivalence o Balkanu in zacementirali idejo perifernega območja kot evropskega soda smodnika (Todorova 2009: 118-19). Balkanistični pristopi so ostali vitalni tudi pri razumevanju različnih dogodkov označevanja stote obletnice sarajevskega atentata $\mathrm{v}$ povojni Bosni in Hercegovini, ki so jih - podobno kot dogodke, ki so vodili $\mathrm{k}$ izbruhu velike vojne - organizirali številni tuji akterji. Toda novinarji in mnogi raziskovalci so slovesnosti pojasnjevali izključno kot odsev bosansko-hercegovskih notranjih etnonacionalnih razkolov, kar so preprosto ilustrirali s podajanjem različnih, nasprotujočih si nacionaliziranih interpretacij Principa.

Jasno je, da je podoba Principa v dvajsetem in enaindvajsetem stoletju doživela številne preobrazbe. Izkoriščali so ga mnogi režimi: za avstro-ogrski imperij je bil Princip terorist in kriminalec, v Jugoslaviji je počasi postajal heroj, označen je bil tudi za juda v času Neodvisne države Hrvaške (Aleksov 2014), bil je tudi revolucionarni junak, srbski mučenik, primitivni upornik, problematičen deček, naivna žrtev, apolitizirana zvezda, vendar tudi mlad, izgubljen fant, pri katerem so se mešali ideali in frustracije (glej Donia 2014). V povojni bosansko-hercegovski družbi, kjer nacionalna segregacija kontinuirano monopolizira javni diskurz ter vpliva tudi na turistično promocijo in trženje sarajevskega atentata, postaja ustaljena navada analizo spominjanja zamejiti na tako imenovano idejo o »bremenu preteklosti «, ki domnevno neustavljivo ločuje konstitutivne narode. Toda etnografske študije obeleževanja obletnice atentata in tudi komodifikacije samega dogodka ponujajo bolj kompleksne podobe in vodijo k ugotovitvi, da tudi danes v sodobni Bosni in Hercegovini Principa ni mogoče preprosto omejiti na dvojno, opozicijsko in izključujočo nacionalizirano podobo $\gg$ terorista « in $\gg$ junaka $\ll$. Uradne turistične naracije $v$ 
Federaciji Bosne in Hercegovine ponujajo drugačne dominantne ideje o Principu, ki odsevajo tudi nove percepcije avstro-ogrskega para ter spremembo dojemanja imperialne zapuščine. Princip je tako naslikan kot mlad, zafrustriran dijak, ki so ga $\mathrm{k}$ nasilnim dejanjem vodile osebne travme in razočaranja. Njegovemu izpričanemu jugoslovanskemu idealizmu se ne zaupa, predvsem pa se naklonjenost jugoslovanski združitvi v turističnih naracijah prezira. Prav tako se o odnosu Principa do srbskega nacionalizma odkrito ne razpravlja. Ne nazadnje pa Princip prevzema podobo neasimiliranega ruralnega Drugega oziroma polruralnega Drugega, ki je zaradi lastnih izkušenj nesprejetosti razvil močan odpor do mest (in $s$ tem tudi do muslimanske elite). Kljub relativni koherenci pri upodabljanju Principa v turističnem diskurzu v Federaciji Bosne in Hercegovine ter izjemno raznolikih doživljanjih Principa pri Sarajevčanih in Sarajevčankah je jasno, da Principa še danes ni mogoče razumeti kot popularno-kulturno ikono ali nevtralnega zvezdnika, ki je povsem odrešen politične moči. Njegova (vsiljena) politična moč je prisotna tudi med državljani Bosne in Hercegovine, ki nasprotujejo politični manipulaciji s preteklostjo. Namreč tudi $\mathrm{v}$ postkonfliktnih družbah se »posamezniki aktivno soočajo z uradnimi zgodovinskimi naracijami $\ll$, tako da $\gg$ nekatere njihove segmente inkorporirajo v svoje osebne naracije, medtem ko druge prezirajo « (Jansen 2007: 207). Osebni (posredovani) spomini v povojni Bosni in Hercegovini velikokrat nasprotujejo nacionaliziranim različicam preteklosti, kar potrjujejo tudi pogovori z delavci v turizmu, ki se ne strinjajo z marginalizacijo Principa v novih reinterpretacijah atentata. Osebni spomini na jugoslovansko obdobje in z njim povezani spomini na Principa imajo prav tako moč, da dekonstruirajo etnonacionalne separacije. V tem pomenu je Princip uporaben tudi kot zgodovinska osebnost, ki uteleša antinacionalistično ideološko pozicijo, saj postaja orodje, $s$ katerim državljani Bosne in Hercegovine ilustrirajo nezadovoljstvo z bosansko-hercegovsko povojno realnostjo, ki je prežeta $s$ persistentno negotovostjo, občutkom izgube, visoko stopnjo brezposelnosti, revščino, korupcijo, državno neučinkovitostjo in podobnim. Pri zavračanju rivalskih nacionalnih interpretacij Principa so prezrti protestniki pred mestno hišo, ki sem jih omenjala $\mathrm{v}$ začetku članka, ponudili alternativno prebiranje atentata. Principa so uporabili kot orodje za produkcijo alternativne uporabne preteklosti. Izpostavljali so zlasti družbeno neenakost in visoke stroške »megaspektakla « (po nekaterih poročilih naj bi slovesnost v Sarajevu Evropsko komisijo stala približno 250.000 evrov), prav tako so se protestniki v Principovih maskah zoperstavili pokroviteljskemu diskurzu o miru in sodelovanju, ki vztrajno premika pozornost na téme, ki poglabljajo konflikte, in se 
odmikajo od pomembnih vprašanj preživetja in dostojnega življenja. $S$ pomočjo Principa so ponavljali politične zahteve, ki so jih podkrepili s slogani $\gg$ Vsi mi smo Princip « ali $\gg$ Znova smo okupirani «. Nekateri protestniki so tudi poudarili, da so slovesnosti organizirali v najbolj neprimernem času, in sicer po tragičnih poplavah, ki so zapustile opustošenje, kar naj bi jasno odražalo prioritete tako lokalnega kot mednarodnega političnega vrha. Protest je bil torej tako javni poziv oblasti kot tudi razkrivanje nevidnih - torej tistih, $s$ katerimi ni moč preprosto manipulirati, prav tako pa je ponudil še eno od platform za oblikovanje kolektivne identitete, ki presega nacionalno segregacijo. V resnici je tovrstna repolitizacija Principa v kontekstu stoletnice pokazala, da obstaja težnja po novi solidarnosti med državljani Bosne in Hercegovine, ki so postali »skupnost izključenih « (Arsenijević 2010: 194; glej tudi Kurtović 2005). Nekdanji veleposlanik Bosne in Hercegovine na Hrvaškem in Bližnjem vzhodu Zlatko Dizdarević je preprosto pojasnil, zakaj nasprotuje komemoracijam sarajevskega atentata:

Te proslave so med nami ponovno zanetile spor o Gavrilu Principu
/.../. Zakaj moramo znova o tem razpravljati? Imamo državo, Bo-
sno in Hercegovino, ki je povsem uničena. Ne deluje. Ne obstaja. In
evropski politiki se bodo z barvitimi baloni in grandioznimi dekla-
racijami prišli smehljat - 'nikoli več', zato da se spomnimo evropske
ljubezni do Sarajeva in opomnimo na evropska načela. To priča o
neverjetnem cinizmu. Če obstaja prostor, kjer so bila vsa evropska na-
čela zavržena, je to Sarajevo /.../. Vse to je cinično. Dogaja se zato, da
pozabimo trenutno realnost Bosne in Hercegovine /.../.V teh prosla-
vah je zelo veliko prazne retorike in sprenevedanja. Sarajevčani nismo
zainteresirani. To niso naše proslave. ${ }^{\mathbf{2 1}}$ (cit. Oskari Rossini 2014)

Dizdarević je podobno kot protestniki strogo kritiziral nov neokolonialni odnos do Bosne in Hercegovine, ki ga je sprejel segment bosansko-hercegovskih prebivalcev, kar ponazarja tudi očitna okrepitev avstronostalgije v bosansko-hercegovski družbi. Hkrati pa Princip služi tudi kot mehanizem za upiranje represivnim dejanjem izbrisa spomina oziroma vsiljene amnezije, kar vpliva tudi na negovanje drugačne nostalgije, in sicer jugonostalgije, ki je povezana s kapaciteto upanja v postsocialističnem kontekstu (glej Jansen 2015; Bartulović 2013; Hage 2009; Luthar in Pušnik 2010; Palmberger 2008; Petrović 2012; Velikonja 2013a; 2013b). In če je avstronostalgijo mogoče pojasniti zlasti kot manifestacijo želja po bosansko-hercegovski evropski integraciji, je jugonostalgija predvsem odsev trajajočih prizadevanj za 


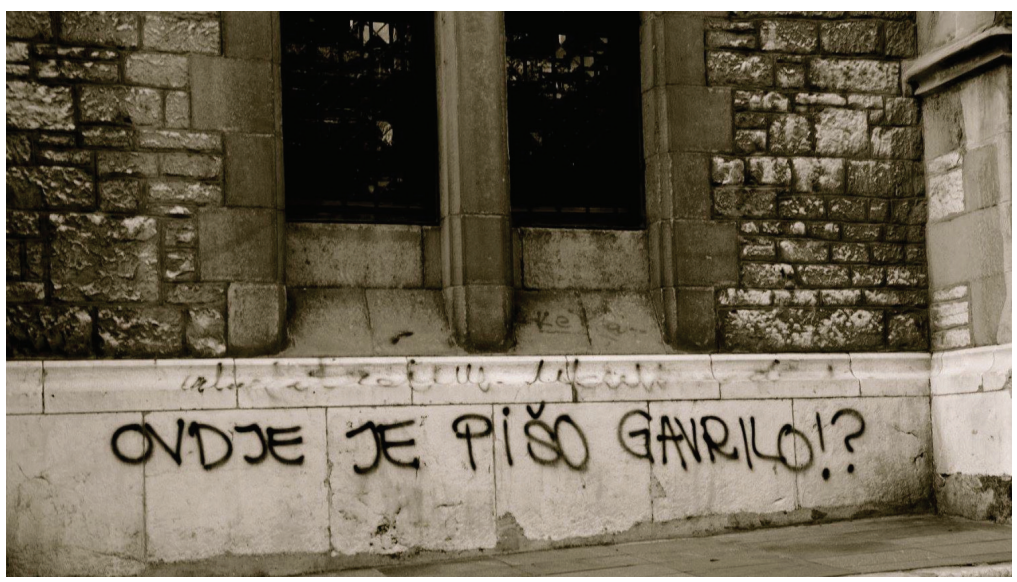

Slika 4: Sarajevski grafit, Sarajevo, november 2018 (foto: Alenka Bartulović)

normalizacijo življenj (glej npr. Jansen 2015). Ironično sta tako oba, nasprotujoča si diskurza, ki si vsak na svoj način prilaščata Gavrila Principa, v veliki meri rezultat globokega nezadovoljstva z bosansko-hercegovsko povojno realnostjo.

Spominjanje atentata kot tudi klici k utišanju debat o Principu in preusmeritvi pozornosti na realne družbene probleme kažejo, da tudi v izjemno nacionaliziranem ozračju spomini ostajajo večinoma heterogeni ter da niso vselej speti zgolj in izključno z nacionalno skupnostjo. Heterogenost kulturnega spomina na sarajevski atentat in njegove osrednje protagoniste, ki se izraža skozi različne diskurze in prakse, kliče k bolj poglobljeni analizi produkcije različnih uporabnih preteklosti v povojnem kontekstu, hkrati pa ponuja argument za nadaljnje, etnografsko utemeljene raziskave transformacijske moči spomina v povojnih družbah.

\section{CITIRANE REFERENCE}

Aleksov, Bojan 2014 Forgotten Yugoslavism and anti-clericalism of Young Bosnians; Prilozi: Contributions, št. 43, str. 79-87.

AlibeČirović-Lunjo, Amir 2003 Gavrilove stopinje; Mladina, 24. marca; http:// www.mladina.si/96373/gavrilove-stopinje/; dostop 19. aprila 2017.

Allcock, John B. 2000 Explaining Yugoslavia. Irvington, New York: Columbia University Press.

2009 Rural-urban differences and the break-up of Yugoslavia; Balkanologie, št. 1-2; str. 101-125. 
Armakolas, IOANNIS 2007 »Sarajevo No More? « Identity and the Experience of Place among Bosnian Serb Sarajevans in Republika Srpska; B. Xavier, G. Duijzings in E. Helms, ur.. The New Bosnian Mosaic: Social Identities, Collective Memories and Moral Claims in a Post-war Society, str. 79-99. Aldershot: Ashgate.

Arsenijević, DAmir 2010 Forgotten Future: Politics of Poetry in Bosnia and Herzegovina. Baden-Baden: Nomos.

Bartulović, Alenka 2013 »Nismo vaši!«: Antinacionalizem v povojnem Sarajevu. Ljubljana: Znanstvena založba FF.

BASKAR, BOJAN 1999 Anthropologists Facing the Collapse of Yugoslavia; Diogenes, št. 4, str. 51-63.

2007 Austronostalgia and Yugonostalgia in the western Balkans; Božidar Jezernik, Rajko Muršič in Alenka Bartulović, ur. Europe and its Other: Notes on the Balkans, str. 45-62. Ljubljana: Oddelek za etnologijo in kulturno antropologijo, Filozofska fakulteta.

Belaj, Marijana, In Nevena ŠKrbić Alimpijević 2014 Remembering 》the Father of the Contemporary State of Croatia «: The Celebration of Tuđman's Birthday in His Birthplace; Traditiones, št. 1, str. 79-109.

Bougarel, XAVIER 1999 Yugoslav Wars: The »Revenge of the Countryside « between Sociological Reality and Nationalist Myth; East European Quarterly, št. 2, str. $157-175$.

Bougarel, Xavier, Elissa Helms in Ger Duijzings, ur. 2007 The New Bosnian Mosaic: Identities, Memories and Moral Claims in a Post-War Society. Aldershot: Ashgate.

BURns, John F. 2014 In Sarajevo, Divisions That Drove an Assassin Have Only Begun to Heal; The New York Times, 26. junija. http://www.nytimes.com/2014/06/27/ world/europe/in-sarajevo-gavrilo-princip-set-off-world- war-i.html?_r=0; dostop 5. aprila 2017.

ČElIĆ, DŽEMAL 1983 Sarajevo i okolica. Zagreb: Turistkomerc.

Dedijer, Vladimir 1966 Sarajevo: 1914. Beograd: Prosveta.

Donia, Robert 2014 Iconography of an Assassin: Gavrilo Princip from Terrorist to Celebrity; Prilozi: Contributions, št. 43, str. 57-78.

EASTMOND, MARITA 2010 Introduction: Reconciliation, reconstruction, and everyday life in war-torn societies; Focaal: Journal of Global and Historical Anthropology, št. 57, str. 3-16.

Hage, Ghassan 2009 Waiting Out the Crisis: On Stuckedness and Governmentality; G. Hage, ur. Waiting, str. 97-106. Melbourne: Melbourne University Press.

HaJdARPAŠIĆ, EdIN 2015 Whose Bosnia? Nationalism and Political Imagination in the Balkans, 1840-1914. Ithaca: Cornell University Press.

HARRINGTON, SELMA 2014 The politics of memory: the face and the place of the Sarajevo Assassination; Prilozi: Contributions, št. 43, str. 113-139.

2015 Djevojka Bosna, carević i Baš-Čelik. Kako smo se sjećali Sarajevskog atentata; Vahidin Preljević in Clemens Ruthers, ur. Sarajevski dugi pucnji 1914. Dogadaj - narativ - pamćenje, str. 567-584. Zenica: Vrijeme Zenica. 
HASANBEgović, NAZIF 2015 Medijski diskursi povodom obilježavanja stogodišnjice Sarajevskog atentata; Vahidin Preljević in Clemens Ruthers, ur. Sarajevski dugi pucnji 1914. Dogadaj - narativ - pamćenje, str. 267-272. Zenica: Vrijeme Zenica.

Helms, Elissa 2003 Women as Agents of Ethnic Reconciliation? Women's NGOs and International Intervention in Post-War Bosnia-Herzegovina; Women's Studies International Forum, št. 1, str. 15-33.

VAn Hendel, Guido 2014 »Up in flames «- Gavrilo Princip and the City; Prilozi: Contributions, št. 43, str. 89-97.

Jansen, Stef 2005 Antinacionalizam: Etnografija otpora u Beogradu i Zagrebu. Beograd: Biblioteka XX vek.

2007 Remembering with a Difference: Clashing Memories of Bosnian Conflict in Everyday Life; Xavier Bougarel, Elissa Helms E. in Ger Duijzings, (ur.). The New Bosnian Mosaic: Identities, Memories and Moral Claims in a Post-War Society, str. 193-208. Aldershot: Ashgate.

2013 If reconciliation is the answer, are we asking the right questions?; Studies in Social Justice, št. 2, str. 229-243.

2015 Yearning in the Meantime: »Normal Lives « and the State in a Sarajevo Apartment Complex. New York, Oxford: Berghahn Books.

JEZERNIK, BOŽIDAR 2015 The nationalisation of the past. Ljubljana: Mladinska knjiga.

Johnston, Anthony PAtrick 2011 Thanatourism and the commodification of war tourism space in ex-Yugoslavia. Galway: School of Geography \& Archaeology Department of Geography, National University of Ireland. Neobjavljena doktorska disertacija.

Kamberović, Husnija 2014 Commemoration of the First World War in Bosnia and Herzegovina; Prilozi: Contributions, št. 43, str. 7-15.

Karačić, Darko, TAmara Banjeglav in Nataša Govedarica 2012 Re:vizija prošlosti: Službene politike sjećanja u Bosni i Hercegovini, Hrvatskoj i Srbiji od 1990. godine. Sarajevo: ACIPS, Friedrich Ebert Stifung.

KAtZ, Vera 2014 Ideological use of the memorial plaques dedicated to Gavrilo Princip in the upbringing and education of generations of youth in Bosnia and Hercegovina; Prilozi: Contributions, št. 43, str. 99-111.

KURTOVIĆ, LARISA 2015 »Who sows hunger, reaps rage«: on protest, indignation and redistributive justice in post-Dayton Bosnia-Herzegovina; Southeast European and Black Sea Studies, št. 4, str. 639-659.

LIPA, AIDA 2006 The Austro-Hungarian Period in Bosnia and Herzegovina: Cultural Politics in Bosnia and Herzegovina ant the Creation of the Western Type of Art; Kakanien Revisited, 26, maja, http://www.kakanien.ac.at/beitr/fallstudie/ ALipa1.pdf; dostop 5. maja 2017.

Lukec, Katarina 2016 »Za jedne on je heroj, a drugima je zločinac « - Gavrilo Princip u popularnoj kulturi 100 godina nakon Sarajevskog atentata; Studia ethnologica Croatica, št. 1, str. 315-337.

Luthar, BRedA, IN MARuša Pušnik, UR. 2010 Remembering Utopia: The Culture of Everyday Life in Socialist Yugoslavia. Washington: New Academia Publishing, LLC. 
Medunjanin, Eldina 2014 Principove stope i spomenik Ferdinandu privukli bi turiste; Večernji list, 19. januarja. http://www.vecernji.ba/principove-stope-i-spomenik-ferdinandu-privukli-bi-turiste-915939; dostop 10. maja 2017.

Mezzofiore, Gianlucca 2014 Franz Ferdinand Assassination: Serb Leaders Boycott Sarajevo Ceremony to Unveil Gavrilo Princip Tribute in Andricgrad; $I B$ Times, 27. junija. http://www.ibtimes.co.uk/franz-ferdinand-assassination-serb-leaders-boycott-sarajevo-ceremony-unveil-gavrilo-princip-1454487; dostop 15. aprila 2017.

Miller, Paul 2014 Yugoslav Eulogies: The Footprints of Gavrilo Princip; The Carl Beck Papers in Russian and East European Studies, št. 2304.

Moll, Nicolas 2015 Majka svih atentata? Sarajevo 1914, Marseille 1934, Dallas 1963, Twin Towers 2001; Vahidin Preljević in Clemens Ruthers, ur. Sarajevski dugi pucnji 1914. Dogadaj - narativ - pamćenje, str. 527-541. Zenica: Vrijeme Zenica.

Oskari Rossini, Andrea 2014 Sarajevo, One Hundred Years; Osservatorio Balcani e Caucaso Transeuropea, 21, maja. https://www.balcanicaucaso.org/eng/Areas/Bosnia-Herzegovina/Sarajevo-One-Hundred-Years-151730; Sarajevo, One Hundred Years; dostop 20. aprila 2017.

Palmberger, Monika 2008 Nostalgia Matters: Nostalgia for Yugoslavia as Potential Vision for a Better Future; Sociologija, št. 4, str. 355-370.

Petrović, TANJA 2012 Yuropa. Jugoslovensko naslede i politike budućnosti u postjugoslovenskim društvima. Beograd: Fabrika knjiga.

Petrović-Ziemer, Ljubinka 2015 Višeznačnost istorijskog lika Gavrila Principa u kontekstu sučeljenih kultura sjećanja u Bosni i Hercegovini; Vahidin Preljević in Clemens Ruthers, ur. Sarajevski dugi pucnji 1914. Dogadaj - narativ - pamćenje, str. 511-526. Zenica: Vrijeme Zenica.

Preljević, Vahidin, in Muamer Spahić 2015 Sarajevo Assassination. Zenica: Vrijeme.

Potkonjak, Sanja, in Tomislav Pletenac 2016 The Art and Craft of Memory: Re-Memorialization Practices in Post-Socialist Croatia; Stijn Vervaet in Vlad Beronja, ur. Post-Yugoslav Constellations: Archive, Memory, and Trauma in Contemporary Bosnian, Croatian, and Serbian Literature and Culture, str. 65-81. Berlin, Boston: Walter De Gruyter.

Ruthner, Clemens 2008 Habsburg's Little Orient: A Post/Colonial Reading of Austrian and German Cultural Narratives on Bosnia-Herzegovina, 18781918; Kakanien revisited, http://www.kakanienrevisited.at/beitr/fallstudie/ CRuthner5.pdf, dostop 10. maja 2016.

Stefansson, Anders 2007 Urban Exile: Locals, Newcomers and the Cultural Transformation of Sarajevo; Xavier Bougarel, Elissa Helms E. in Ger Duijzings, (ur). The New Bosnian Mosaic: Identities, Memories and Moral Claims in a Post-War Society, str. 59-77. Aldershot: Ashgate.

Todorova, Maria 1997 Imagining the Balkans. Oxford: Oxford University Press.

Velikonja, Mitja 2013a Between collective memory and political action: Yugonostalgia in Bosnia-Herzegovina; Ola Listhaug in Sabrina Ramet, ur. Bosnia-Herzegovina since Dayton: civic and uncivic values, str. 351-368. Ravenna: A. Longo. 
2013b The past with a future: the emancipatory potential of Yugonostalgia; Srdja Pavlović in Marko Živković, ur. Transcending fratricide: political mythologies, reconciliations, and the uncertain future in the former Yugoslavia, str. 351-368. Baden-Baden: Nomos.

2018 Contested Heroes - Gavrilo Princip and Rudolf Maister as Subcultural Icons; Traditiones, št. 1, str. 213-229.

Vervaet, Stijn 2016 Revolutionaries or Terrorists, Heroes or Victims? Young Bosnia and Gavrilo Princip in Biljana Srbljanović's Theater Play »Mali mi je ovaj grob «; Clemens Ruthner in Vahidin Preljević, ur. The Long Shots of Sarajevo: 1914: Ereignis - Narrativ - Gedächtnis, str. 551-566. Tübingen: Narr Francke Attempo.

Vervaet, Stijn in Vladislav Beronja 2016 Introduction: After Yugoslavia - memory on the ruins of history; Stijn Vervaet in Vlad Beronja, ur. Post-Yugoslav Constellations: Archive, Memory, and Trauma in Contemporary Bosnian, Croatian, and Serbian Literature and Culture, str. 1-20. Berlin: De Gruyter.

WeRtsch, JAmes V. 2002 Voices of collective remembering. Cambridge: Cambridge University Press.

\section{Spletni viri}

Sarajevo Foundation Heart of Europe - Press Kit, Press Conference; http://europa.ba/ wp-content/uploads/2015/05/delegacijaEU_2014053010500312eng.pdf; dostop 20. aprila 2017.

Sarajevo 1914-2014: 1 City, 3 Wars, 1 Olympic = 1 Lesson. 2014. R2.1 multimedia. http:// resilience21.com/mapping-sarajevo-1914-2014/, dostop 12. aprila 2017. 